\title{
Anti-immunoglobulin antisera used in an ELISA to detect antibodies in barramundi Lates calcarifer to Cryptocaryon irritans
}

\author{
M. S. Bryant ${ }^{1, *}$, R. P. Lee ${ }^{1}$, R. J. G. Lester ${ }^{1}$, R. J. Whittington ${ }^{2}$ \\ ${ }^{1}$ Department of Parasitology, The University of Queensland, Brisbane, 4072, Australia \\ ${ }^{2}$ Elizabeth Macarthur Agricultural Institute, PMB 8, Camden, 2570, Australia
}

\begin{abstract}
Immunoglobulins ( $\mathrm{lg}$ ) in serum from barramundi vaccinated with bovine serum albumin (BSA) were purified by ammonium sulphate precipitation and affinity chromatography using BSA as the ligand. The BSA-binding activity of eluted putative Ig fractions was assessed by enzyme-linked immunosorbent assay (ELISA) before being pooled and characterised by sodium dodecyl sulphate polyacrylamide gel electrophoresis (SDS-PAGE). Double affinity purification did not improve the purity of the Ig preparation compared to single affinity purification. Barramundi Ig were injected into sheep to produce anti-Ig antisera which were assessed in an indirect ELISA as the secondary antibody to detect serum Ig in barramundi vaccinated with Cryptocaryon irritans theronts. Affinity-purified Ig induced a more specific reagent for use as secondary antibody in ELISA than did normal whole-barramundi sera. The heavy $(H)$ chain of barramundi Ig had an apparent molecular weight of $70 \mathrm{kDa}$ while that of the light (L) chain was $27 \mathrm{kDa}$ in SDS-PAGE studies. Under non-reducing conditions 2 putative populations of $\mathrm{Ig}$ were identified, at 768 and $210 \mathrm{kDa}$. The $\mathrm{N}$-terminal sequence of the barramundi Ig $\mathrm{H}$ chain showed $78 \%$ homology with channel catfish Ictalurus punctatus Ig H chain sequence
\end{abstract}

KEY WORDS: Cryptocaryon irritans · Antibodies · ELISA · Serology - Immunoglobulin · Barramundi Lates calcarifer . Disease - Teleost

\section{INTRODUCTION}

Cryptocaryon irritans (Brown, 1951) is a holotrichous ciliate parasite and is the marine equivalent of Ichthyophthirius multifiliis, which causes white spot disease. The infective stage of the parasite (theront) penetrates into the epithelium of the skin and gills of marine fishes where it feeds and increases in size over several days, forming visible white spots on the host epithelium (trophont stage). The mature trophonts leave the host, sink to the substrate and encyst to form tomonts. After several divisions the cyst ruptures to release several hundred actively swimming theronts which must find a fish to continue the life cycle. White spot disease kills fish in marine aquaria throughout the world (Nigrelli \& Ruggieri 1966, Andrews et al. 1988,

-Present address: Queensland Museum, PO Box 3300, South Brisbane, 4101, Australia.E-mail: malb@qm.qld.gov.au
Sindermann 1990) and is also of concern in commercial mariculture, affecting a range of cultured species, including brown-spotted grouper Epinephelus tauvina (Rasheed 1989); gilt-head sea bream Sparus aurata and European sea bass Dicentrarchus labrax (Diamant et al. 1991); grouper Epinephelus malabaricus and seabass Lates calcarifer (Leong \& Wong 1990); and snapper Lutjanus johni (Leong 1992).

Fish can acquire resistance to Ichthyophthirius multifiliis, the cause of white spot disease in freshwater fishes. Hines \& Spira (1974) found that mirror carp Cyprinus carpio were refractory to re-infection following exposure to sublethal doses of $I$. multifiliis, while Clark et al. (1987) demonstrated similar responses from channel catfish Ictalurus punctatus. Colorni (1987) noted that fish that had survived several infections of Cryptocaryon irritans acquired a certain degree of immunity, indicating it may be possible to protect fish by vaccination. 
The present investigation was part of a larger study conducted to investigate the humoral immune responses of barramundi Lates calcarifer following exposure to Cryptocaryon irritans antigens. This research necessitated the production of anti-barramundi antiserum for use in enzyme-linked immunosorbent assay (ELISA), as this reagent was not available commercially. Barramundi were chosen as an experimental host because this species is important in commercial aquaculture in Australia, is affected by white spot disease in Southeast Asian aquaculture (Seng 1987, Leong \& Wong 1990), and is euryhaline and because hatchery raised fish are readily available for experimental purposes.

\section{MATERIALS AND METHODS}

Cryptocaryon irritans propagation and collection of theronts. An isolate of $C$. irritans was obtained from infected bream Acanthopagrus australis caught in the Brisbane River, Queensland, Australia, then propagated by serial passage using naive barramundi. Tomonts were collected from tanks of infected fish, cleaned with several washes of filtered seawater (FSW) and incubated at 28 to $30^{\circ} \mathrm{C}$ in FSW at $30 \%$ salinity. Theronts to be used as antigen were collected after excystment from the tomonts, cleaned with FSW, sonicated and assayed for protein concentration by a modified Lowry assay (Markwell et al. 1978).

Immunisation of barramundi. Barramundi (30 to $35 \mathrm{~cm}$ total length), kept at 27 to $29^{\circ} \mathrm{C}$, were immunised by intraperitoneal (IP) injection of $0.1 \mathrm{ml}$ doses of vaccine given at least $3 \mathrm{wk}$ apart. Four fish were injected with a total of $1.25 \mathrm{mg}$ of bovine serum albumin (BSA) from 4 injections and 3 fish were injected with about $735 \mu \mathrm{g}$ of sonicated Cryptocaryon irritans theronts from 3 injections. The primary vaccines were emulsified 1:1 with Freund's complete adjuvant (FCA) and the 2 booster injections were prepared by emulsifying antigens 1:1 with Freund's incomplete adjuvant (FIA). Fish were bled periodically from the caudal vein, blood was allowed to clot overnight at $4^{\circ} \mathrm{C}$, then centrifuged at $1000 \times g$ for $10 \mathrm{~min}$ and serum was stored at $-20^{\circ} \mathrm{C}$

Immunisation of sheep. Merino-cross sheep less than 1 yr old were given 3 intramuscular (IM) injections over $6 \mathrm{wk}$ of $2 \mathrm{ml}$ doses of vaccine containing either normal whole-barramundi serum or purified barramundi immunoglobulins (Ig) mixed with Quil A at $1 \mathrm{mg} \mathrm{ml}^{-1}$ in phosphate buffered saline (PBS), $\mathrm{pH}$ 7.2. Two sheep were each injected with a total of $650 \mu \mathrm{g}$ of normal barramundi serum and 1 sheep was injected with a total of $400 \mu \mathrm{g}$ of purified barramundi Ig. Sheep were bled from the jugular vein; blood was allowed to clot as before, then was centrifuged as before and serum was stored at $-20^{\circ} \mathrm{C}$

Purification of barramundi Ig. Ig was precipitated at room temperature (RT) from $2 \mathrm{ml}$ of both normal barramundi serum and serum from barramundi injected with BSA by slow dropwise addition of saturated ammonium sulphate, while constantly stirred, to a final concentration of $50 \% \mathrm{v} / \mathrm{v}$. The precipitate was separated from the suspension by centrifugation at $10000 \times g$ for $10 \mathrm{~min}$, then the pellet was resuspended in $2 \mathrm{ml} 0.1 \mathrm{M}$ phosphate buffer. The precipitation procedure was repeated twice, after which the final resuspended precipitate was dialysed at $4^{\circ} \mathrm{C}$ against $0.1 \mathrm{M}$ phosphate buffer then stored at $-20^{\circ} \mathrm{C}$.

Affinity chromatography columns were prepared by coupling BSA $\left(10 \mathrm{mg} \mathrm{ml}^{-1}\right.$ of gel) to $10 \mathrm{ml}$ of CNBractivated Sepharose 4B (Pharmacia) according to the manufacturer's instructions and equilibrated with $0.1 \mathrm{M}$ phosphate, 0.15 $\mathrm{M} \mathrm{NaCl}$ buffer, $\mathrm{pH} 7.4$.

Ammonium sulphate purified Ig from $2.4 \mathrm{ml}$ total volume of either normal barramundi serum, used as a control or barramundi anti-BSA serum were incubated on the column for $1 \mathrm{~h}$ at RT. Bound material was eluted with $0.1 \mathrm{M}$ glycine buffer, $\mathrm{pH} 2.8$ and fractions were neutralised with $2.75 \mathrm{M}$ Tris. The protein concentration was determined by absorbance at $280 \mathrm{~nm}$ and then fractions were buffer exchanged to $0.15 \mathrm{M}$ PBS using Microcon microconcentrators (Amicon) and stored at $-20^{\circ} \mathrm{C}$.

Affinity-purified Ig from barramundi anti-BSA serum were subjected to a second affinity purification procedure using the method described above and final concentrations of protein in all purified samples were estimated using the modified Lowry assay mentioned previously.

ELISA. A standard protocol for ELISA was followed after optimisation of the concentrations of antigen, test sera, secondary antibody and conjugate. Typically 1 or 2 of the reagents were titrated on the ELISA plates using doubling dilutions while the other reagents were kept at a selected concentration. From plots of optical density (OD) versus dilution of reagents, optimal concentrations were selected so that antigen, anti-barramundi antisera and conjugate were not limiting and there was at least a 3 -fold difference in OD between immunised and non-immunised fish sera.

BSA and sonicated Cryptocaryon irritans theront antigens were diluted in $60 \mathrm{mM}$ carbonate buffer, $\mathrm{pH} 9.6$, and coated on to polystyrene 96-well plates (Disposable Products Cat. no. 23148 ) overnight at $4^{\circ} \mathrm{C}$, with $100 \mu \mathrm{l}$ volumes of diluted antigen added to each well. Plates were blocked with $1 \% \mathrm{w} / \mathrm{v}$ gelatin in carbonate buffer, $150 \mu \mathrm{l}$ well $^{-1}$, and incubated at $37^{\circ} \mathrm{C}$ for $1 \mathrm{~h}$. After washing 3 times with $0.15 \mathrm{M}$ PBS with $0.05 \% \mathrm{v} / \mathrm{v}$ Tween 20 (PBS-T), test samples of fish sera 
diluted in PBS-T were added, $100 \mu \mathrm{l}$ well $^{-1}$, to the plates and incubated as before. Plates were washed and fish antibodies were detected with either the sheep anti-barramundi serum or the sheep anti-barramundi Ig serum, diluted in PBS-T, and then incubated as before. Plates were washed and rabbit anti-sheep IgG conjugated to horseradish peroxidase (Cappel), diluted in PBS-T, was added and incubated as before. Plates were washed and 2,2'azino-bis(3-ethylbenzthiazoline6-sulfonic acid) (ABTS) chromogen in $50 \mathrm{mM}$ citrate buffer, $\mathrm{pH} 4.0,0.1 \mathrm{mM}$ hydrogen peroxide was added. Plates were read at $405 \mathrm{~nm}$, when OD values for positive control wells reached 0.6 , on either a Titretek Multiscan (Flow Laboratories) or a Biorad Microplate reader (Model 3550) linked to Microplate Manager III (Biorad).

SDS-PAGE. Proteins in normal barramundi serum and single and double affinity-purified barramundi Ig preparations were separated, according to Laemmli (1970), in a 10\% reducing sodium dodecyl sulphate polyacrylamide gel, containing 37.5:1 acrylamide:bisacrylamide. After electrophoresis, the gel was stained with Coomassie brilliant blue (CBB). The apparent molecular weights (MW) were estimated from $\mathrm{MW}$ standards (Low Range Biorad) and purified Ig from mullet Chelon labrosus (gift from Peter Burgess) which were run concurrently.

Affinity-purified barramundi Ig were analysed under non-reducing conditions in a $3 \%$ gel, with samples diluted in buffer that did not contain $\beta$-mercaptoethanol. After electrophoresis, the gel was stained with B/T Blu (BT Scientific Technologies, San Diego). The apparent MW of unreduced Ig and subunits were estimated from the following standards run concurrently: human IgM (Sigma), bovine thyroglobulin (Sigma) and bovine IgG (Sigma).

$\mathbf{N}$-terminal sequencing. Proteins in single affinity-purified barramundi Ig were separated on a $10 \%$ reducing gel as described above except that the running buffer also contained $0.1 \mathrm{mM}$ thioglycolate. Separated proteins were electrophoretically transferred to $0.2 \mu \mathrm{m}$ PVDF membrane (Biorad), which was then stained with CBB. Stained bands were cut from the membrane, sequenced using an ABI 473A pulsed liquid protein sequenator and then compared to sequence data from GenBank and SWISS-PROT databases using the Australian National Genomic Information Service (ANGIS) FastA program.

\section{RESULTS}

\section{Calibration of ELISA and response of fish to immunisation}

Optimisation of ELISA by titration of reagents led to the selection of the following concentrations: BSA antigen coated to plates at $5 \mu \mathrm{g} \mathrm{ml}^{-1}$; barramundi anti-BSA sera diluted 1:200; sonicated Cryptocaryon irritans theront antigen coated to plates at $15 \mu \mathrm{g} \mathrm{ml} \mathrm{m}^{-1}$; barramundi anti-C. irritans theront sera diluted 1:400; sheep antiserum against normal barramundi serum and sheep antiserum against purified barramundi Ig diluted $1: 3200_{i}$ and HRP-conjugated rabbit anti-sheep serum diluted 1:1600.

The 4 barramundi injected with BSA had variable responses to immunisation, with 1 fish showing a minimal response (Fig. 1). Peak responses were at Week 8,2 wk after the third injection. Serum samples from the most responsive fish, L6, which had OD levels twice that of the second most responsive fish, were pooled for purification of barramundi Ig

\section{Affinity chromatography of precipitated barramundi Ig}

Ammonium sulphate precipitation reduced the total serum protein from normal and immune barramundi serum by $42 \%$ and $47-57 \%$ respectively.

Ig precipitated from normal barramundi serum did not bind to the BSA column, while Ig from vaccinated fish purified either once or twice by affinity chromatography were eluted from the column after application of glycine buffer. Anti-BSA Ig activity was

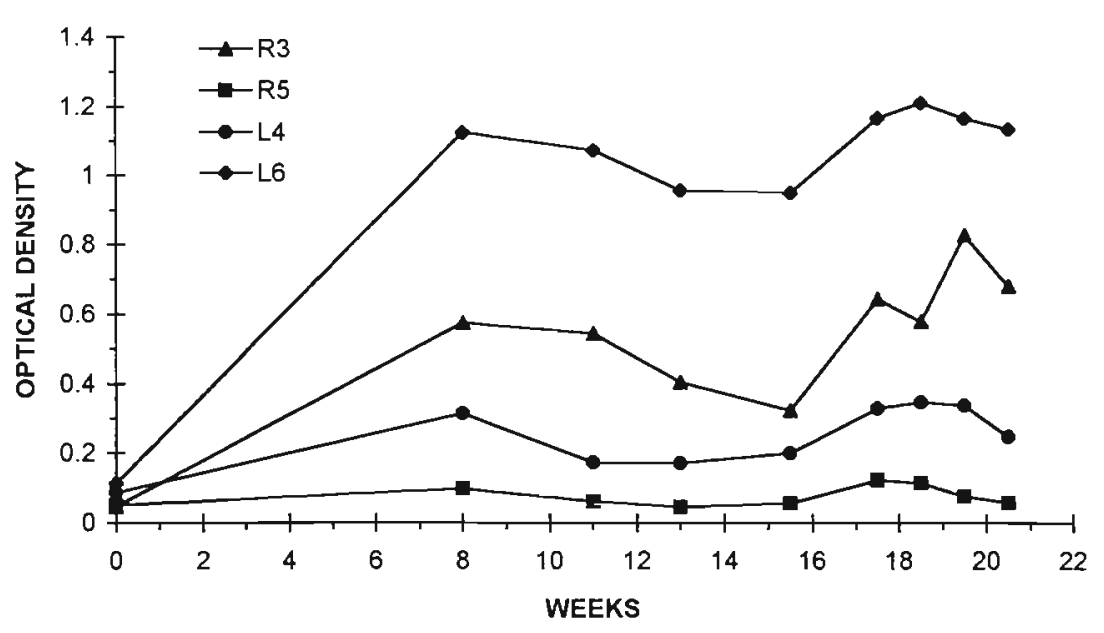

Fig. 1. Lates calcarifer. Humoral antibody responses, measured by ELISA against bovine serum albumin (BSA), from 4 barramundi injected with BSA. Fish were injected at Weeks $0,3,6$ and 15.5 so that each fish received a tatal of $1.25 \mathrm{mg}$ of BSA. Pre-bleed (PB) sera samples were taken before vaccination and immunebleed (IB) sera samples were taken at intervals after the third injection 


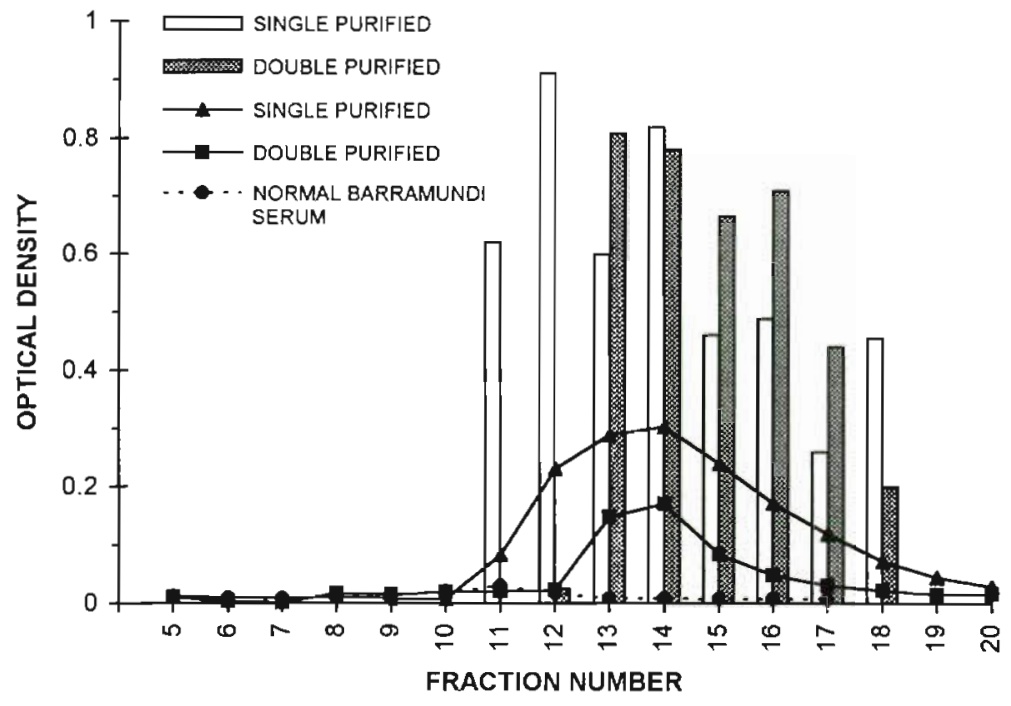

Fig. 2. Protein levels (optical density [OD] at $280 \mathrm{~nm}$ ) in fractions eluted from an affinity chromatography column, with BSA as the ligand, following single affinity purification of normal barramundi serum, single affinity purification of barramundi anti-BSA serum and double affinity purification of barramundi anti-BSA serum. Columns represent anti-BSA immunoglobulin levels, measured by ELISA (OD at $405 \mathrm{~nm}$ ), in eluted fractions of single affinity-purified barramundi anti-BSA serum and double affinitypurified barramundi anti-BSA serum corresponding to the protein profiles

\section{N-terminal sequencing}

The putative barramundi Ig heavy $(\mathrm{H})$ chain, corresponding to the major band of approximately $70 \mathrm{kDa}$ on reducing SDS-PAGE, had a sequence of 'EQLTPASVTVQPG'. When compared with other reported protein sequences, it was found to have $78.6 \%$ identity in a 14 amino acid overlap with channel catfish Ictalurus punctatus Ig $\mathrm{H}$ chain $\mathrm{V}$ region, $78.6 \%$ identity in a 14 amino acid overlap with $I$. punctatus Ig $\mathrm{H}$ chain mRNA $\mathrm{V}$ region and $76.9 \%$ identity in a 13 amino acid overlap with human Ig rearranged light (L)-chain mRNA V region (Table 1 ).

\section{Assessment of two sheep antisera as marker antibodies in ELISA}

Sheep anti-barramundi Ig serum had greater specificity than sheep anti-barramundi whole serum. OD levels for preimmunisation bleed (PB) sera from 3 barramundi injected with Cryptocaryon irritans theronts were $0.243,0.22$ and 0.182

related by ELISA to these protein profiles (Fig. 2). The highest yield of purified barramundi Ig was obtained from eluted fractions of single affinity-purified antibodies which when pooled had a protein concentration of $140 \mu \mathrm{g} \mathrm{ml}^{-1}$ for a total volume of $15.6 \mathrm{ml}$. The yield of Ig was $2184 \mu \mathrm{g}$ from the $2 \mathrm{ml}$ sample of barramundi anti-BSA sera.

\section{SDS-PAGE}

Normal barramundi serum had $>10$ protein bands between 14.4 and $97.4 \mathrm{kDa}$ and 4 bands $>97.4 \mathrm{kDa}$ (Fig. 3). In contrast, affinity-purified (both single and double) barramundi Ig loaded in high concentration had only 2 major bands at approximately 70 and $27 \mathrm{kDa}$. Resolution of the $70 \mathrm{kDa}$ band indicated the possibility of several components. There was little difference in apparent purity between single and double affinity-purified samples. The purified mullet Ig, run concurrently, had 2 major bands at approximately the same MW as the purified barramundi immunoglobulin, but was of lower concentration.

Under non-reducing conditions a sample of affinitypurified barramundi Ig had 2 major bands (Fig. 4). From the calibration curve prepared from the relative mobilities of the controls that were run concurrently, the MW of these bands were estimated to be 768 and $210 \mathrm{kDa}$ while those for post-immunisation bleed (IB) sera were $0.54,0.42$ and 0.82 when sheep anti-barramundi

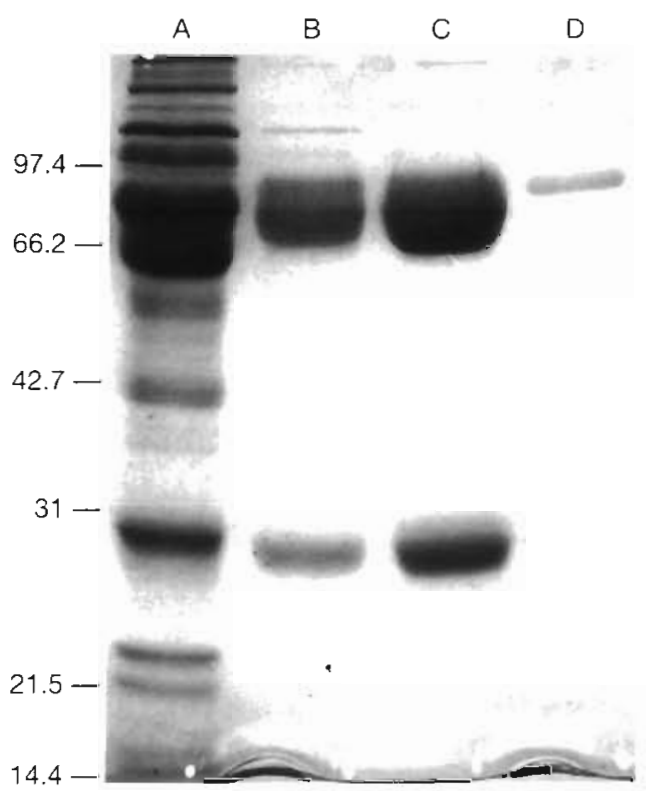

Fig. 3. SDS-PAGE analysis in a 10\% gel under reducing conditions comparing normal barramundi serum (lane A), single affinity-purified barramundi immunoglobulin (lane B), double affinity-purified barramundi immunoglobulin (lane C) and purified mullet immunoglobulin (lane D). The gel was stained with Coomassie brilliant blue (CBB) 


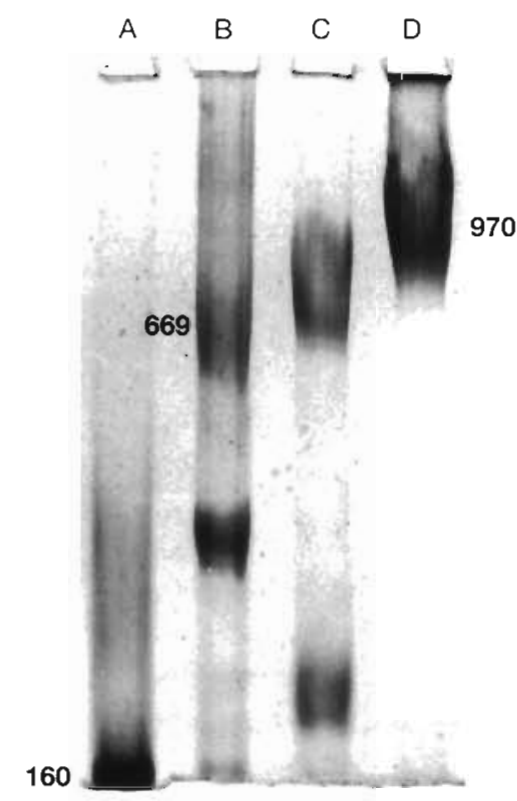

Fig. 4. SDS-PAGE analysis in a $3 \%$ gel under non-reducing conditions comparing bovine IgG, approx. molecular weight $160 \mathrm{kDa}$ (lane A); bovine thyroglobulin, approx. molecular weight $669 \mathrm{kDa}$ (lane B); affinity-purified barramundi immunoglobulin (lane $C_{\text {) }}$ and human IgM, approx. molecular weight $970 \mathrm{kDa}$ (lane D). The gel was stained with B/T Blu

Ig serum was used as the secondary antibody. The corresponding $O D$ levels for the same fish sera when sheep anti-barramundi whole serum was used were $0.432,0.447$ and 0.36 for $\mathrm{PB}$ sera and $0.557,0.49$ and 0.763 for IB sera. The mean difference in OD between pre- and post-immunisation sera was increased 2 -fold for the 3 fish injected with $C$. irritans theronts. Similarly, for the most responsive fish injected with BSA the $O D$ level for IB serum was increased by approxi-
Table 1. Comparison of N-terminal amino acid sequence of affinity-purified barramundi Ig heavy $(\mathrm{H})$ chain with protein sequences sourced through the Australian National Genomic Information Service (ANGIS). B28835: channel catfish Ictalurus punctatus Ig $\mathrm{H}$ chain $\mathrm{V}$ region (3D11) (21 aa); ICTIGHVJ_1: I. punctatus Ig $\mathrm{H}$ chain mRNA V region, cl (132 aa); HUMIG1L_1: Homo sapiens Ig rearranged light (L) chain mRNA $V$ region (106 aa).

\begin{tabular}{|c|c|}
\hline \multirow[t]{2}{*}{$\begin{array}{l}\text { Barra Ig } \\
\text { B28835 }\end{array}$} & $\begin{array}{l}10 \\
\text { EQLT-PASVTVQPG } \\
\text { EELTQPASMTVQPGQSTNDST }\end{array}$ \\
\hline & $10 \quad 20$ \\
\hline \multirow[t]{2}{*}{$\begin{array}{l}\text { Barra Ig } \\
\text { ICTIGHVJ_1 }\end{array}$} & $\begin{array}{c}10 \\
\text { EQLT-PASVTVQPG } \\
\text { LAAASYVHGEELTOPASMTVQPGQSLS }\end{array}$ \\
\hline & $\begin{array}{lll}10 & 20 & 30\end{array}$ \\
\hline $\begin{array}{l}\text { Barra Ig } \\
\text { HUMIG1L_1 }\end{array}$ & $\begin{array}{c}10 \\
\text { EQLT-PASVTVQPG } \\
\text { QSQLTQPASVSVSPGOTASITCSGD }\end{array}$ \\
\hline & 10 \\
\hline
\end{tabular}

mately 0.36 when the sheep anti-barramundi Ig antisera was used (Fig. 5).

\section{Comparison of humoral responses of fish injected with BSA and with Cryptocaryon irritans theronts}

The humoral Ig reponses from both groups of vaccinated fish were monitored over $15.5 \mathrm{wk}$ for 4 fish injected with BSA and 17 wk for 3 fish injected with Cryptocaryon irritans theronts. All sera were diluted 1:400 and analysed on the same ELISA with the same positive and negative controls. The responses from both groups of injected fish showed peaks at $8 \mathrm{wk}$ ( 2 wk after the third injections) with gradual declines
Fig. 5. Lates calcarifer. Humoral antibody levels, measured by ELISA against sonicated Cryptocaryon irritans theront antigen and BSA respectively, in the sera of each of 3 barramundi (L7, L8 and L9) injected with a total of $735 \mu \mathrm{g}$ of sonicated $C$. irritans theront protein and of 1 barramundi (L6) injected with a total of $1 \mathrm{mg}$ of BSA at 3 vaccinations $3 \mathrm{wk}$ apart. Pre-bleed (PB) sera samples were taken before vaccination and immune-bleed (IB1) sera samples were taken $2 \mathrm{wk}$ after the third injection. Fish antibodies were detected with antisera from sheep injected with normal barramundi serum (open bars) and sheep injected with affinity-purified barramundi immunoglobulins (shaded bars)

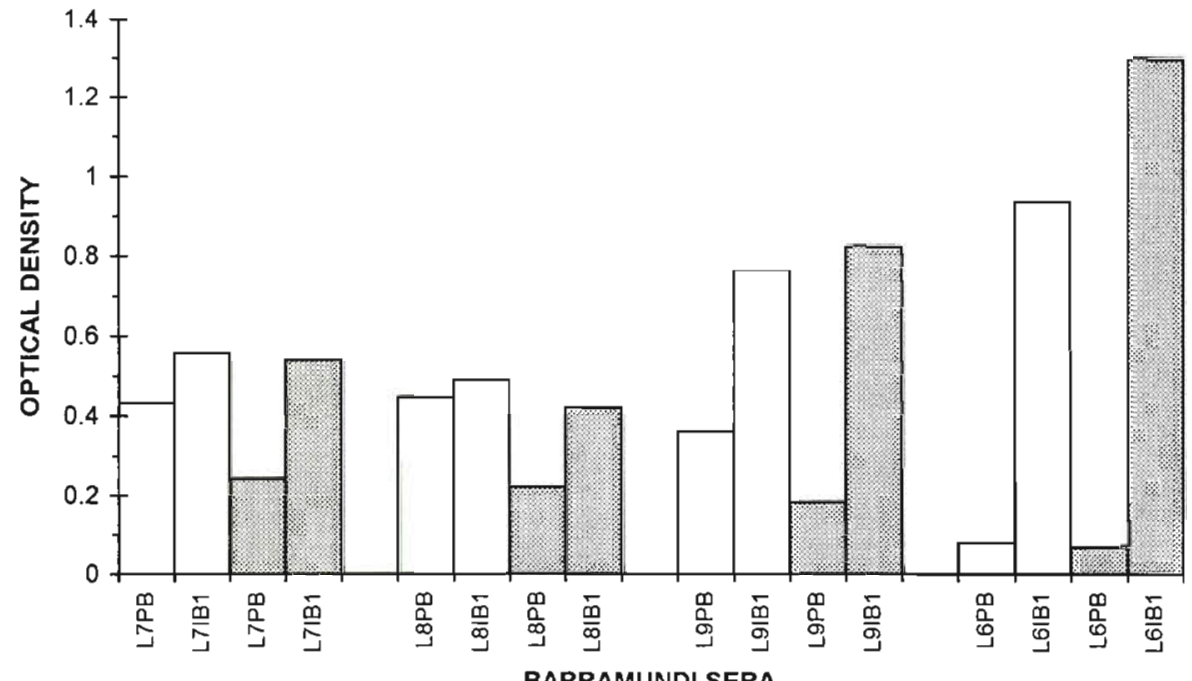



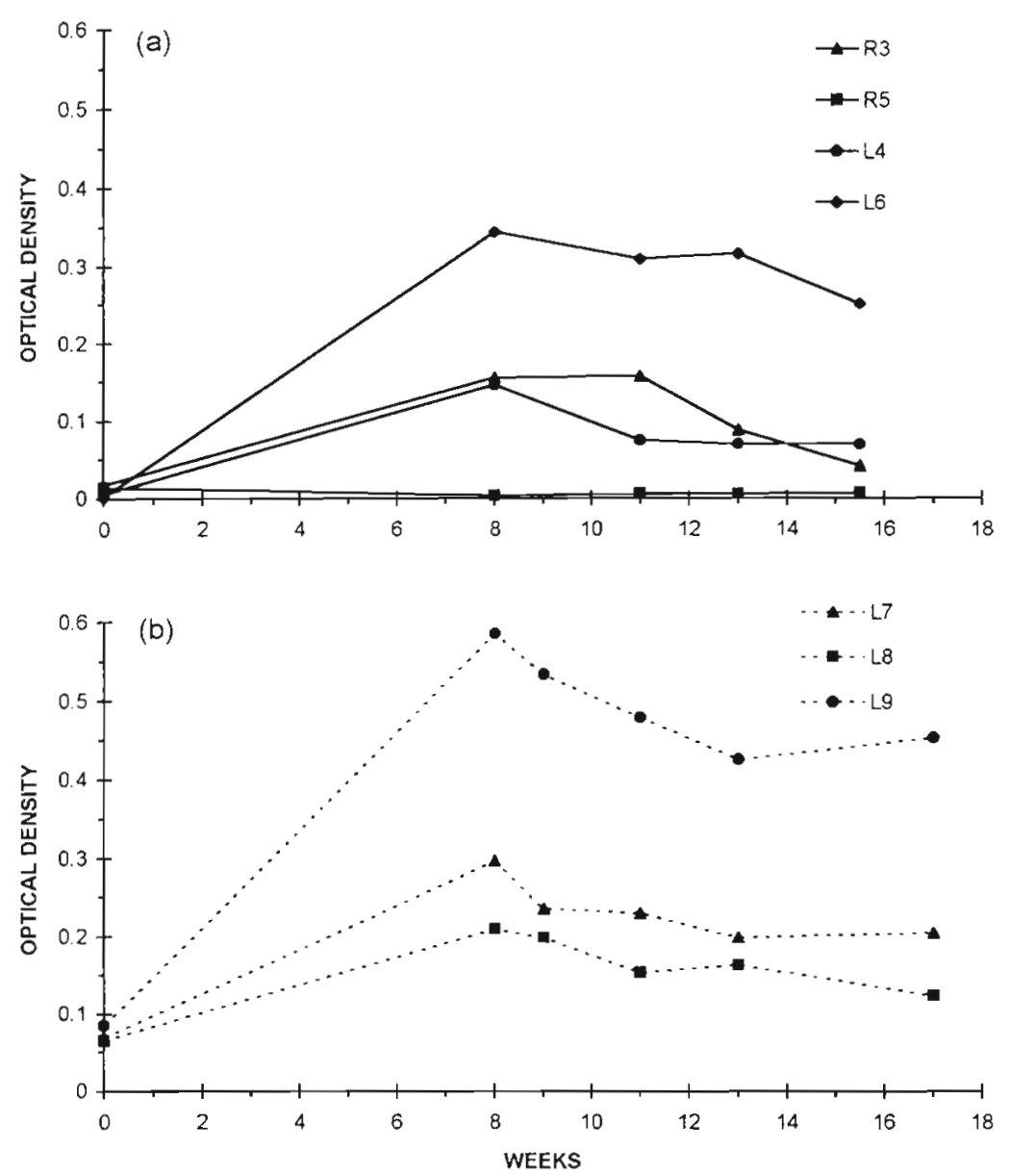

Fig. 6. Humoral antibody levels, measured by ELISA against (a) BSA and (b) sonicated Cryptocaryon irritans theront antigen, from the sera of 4 barramundi injected with a total of $1 \mathrm{mg}$ of BSA and 3 barramundi injected with a total of $735 \mu \mathrm{g}$ of sonicated $C$. irritans theront protein at 3 vaccinations $3 \mathrm{wk}$ apart (Weeks 0, 3 and 6). Pre-bleed (PB) sera samples were taken before vaccination and immune-bleed (IB) sera samples were taken at intervals from 2 wk after the third injection

thereafter (Fig. 6). Both groups showed variations in response, with 1 fish injected with BSA being a nonresponder

\section{DISCUSSION}

Almost half of the irrelevant serum proteins in immune barramundi sera were removed by ammonium sulphate precipitation before the anti-BSA Ig were purified by affinity chromatography. The yield of approximately $2 \mathrm{mg}$ of purified Ig from just $2 \mathrm{ml}$ of immune barramundi sera demonstrates the utility of this protocol. Ellis (1989) reported the concentration of Ig in teleost serum to generally be $2-7 \mathrm{mg} \mathrm{m}^{-1}(6-15 \%$ of total serum protein); this would mean the affinity purification recovered $16-55 \%$ of the $\mathrm{lg}$.
The reduction in background levels on ELISA when using antisera from sheep injected with purified barramundi Ig compared to sheep injected with normal barramundi serum highlights the need to purify immunoglobulins in order to produce specific antisera for use as markers in ELISA. Similar results were reported by Whittington \& Speare (1996) for antisera produced by rabbits to cane toad serum and purified cane toad immunoglobulin. From work to evaluate nonspecific reactivity in the ELISA (authors' unpubl. data) it was concluded that barramundi serum components, including non-immunoglobulins, were binding non-specifically to Cryptocaryon irritans antigen and were thus being detected by the sheep anti-barramundi whole serum.

SDS-PAGE analysis of normal barramundi serum and of affinity-purified barramundi anti-BSA Ig showed that the protocol followed was very effective in purifying barramundi Ig. Double affinity chromatography did not appreciably improve the purity of the sample. The MW of the 2 principal bands present in purified barramundi Ig were indicative of putative $\mathrm{H}$ and $\mathrm{L}$ chains of IgM, which is the predominant immunoglobulin in the serum of teleost fish. Apart from MW, the intensity of staining was consistent with a characteristic of Ig in that the $\mathrm{H}$ chains, being bigger than $\mathrm{L}$ chains, take up more stain. Lobb \& Clem (1983) characterised channel catfish Ictalurus punctatus Ig with $\mathrm{H}$ and $\mathrm{L}$ chains of 70 and $23 \mathrm{kDa}$, respectively. Havarstein et al. (1988) reported $\mathrm{H}$ and $\mathrm{L}$ chains of 72 and $27 \mathrm{kDa}$ for Atlantic salmon Salmo salar, and Pilstrom \& Petersson (1991) reported $\mathrm{H}$ and $\mathrm{L}$ chains of 81 and $27.5 \mathrm{kDa}$ for Atlantic cod Gadus morhua. Similarly, Navarro et al. (1993) reported $\mathrm{H}$ and $\mathrm{L}$ chains of 70 and $25 \mathrm{kDa}$, respectively, for gilthead sea bream Sparus aurata; Whittington (1993) reported $\mathrm{H}$ and $\mathrm{L}$ chains of 72 and $28 \mathrm{kDa}$, respectively, for European perch Perca fluviatilis, and Estevez et al. (1994) reported $\mathrm{H}$ and $\mathrm{L}$ chains of 78 and $27 \mathrm{kDa}$ for turbot Scophthalmus maximus.

Although the high concentration of protein may have contributed to broad diffuse banding on SDS-PAGE, there was a suggestion that the $\mathrm{H}$ and $\mathrm{L}$ chain bands were not homogenous populations. The broad bands in the $\mathrm{H}$ and $\mathrm{L}$ regions (Fig. 3 ) may indicate variations in migration of possible subclasses of antibodies. Isotypes of $\mathrm{H}$ chains have been reported in serum from sheeps- 
head Archosargus probatocephalus (Lobb \& Clem 1981); channel catfish (Lobb \& Olson 1988); rainbow trout Salmo gairdneri (Sanchez et al. 1989); and European perch (Whittington 1993) Similarly, isotypes of $L$ chains have been reported in channel catfish (Lobb et al. 1984) and rainbow trout (Sanchez et al. 1989, Sanchez \& Dominguez 1991), and Whittington (1993) suggested this may also be the case for European perch.

Under non-reducing conditions the affinity-purified barramundi Ig were shown to consist of 2 distinct populations. The high MW (HMW) band, being of slightly lower MW than the pentameric human IgM, suggests a tetrameric structure which is characteristic of teleost IgM. The low MW (LMW) band suggests a monomeric structure slightly larger than bovine IgG, and as the MW is greater than a quarter of the HMW molecule, it may represent a unique Ig population and not just a dissociated portion of the tetramer. Something that must be borne in mind, however, is the difficulty of accurate MW estimation. Warr (1982) reported anomalies in the migration of standards of MW less than $100 \mathrm{kDa}$ in non-reducing SDS-PAGE, and Butler (1983) also reported anomalous migration of Ig subunits in gels. Whittington (1993) observed that a proportion of HMW Ig from European perch may consist of tetramers formed by 4 non-covalently linked subunits which dissociate under conditions that would not cause dissociation of mammalian IgM. To test that this was also the case for barramundi Ig the LMW band would need to be analysed under reducing conditions looking for differences in MW of $\mathrm{H}$ chains compared to the HMW Ig H chains, which would indicate an Ig population unique from the HMW Ig.

The $\mathrm{N}$-terminal sequencing results for the $\mathrm{H}$ chain band, to our knowledge the first reported sequence for barramundi immunoglobulin, reinforce the data from SDS-PAGE and confirm that the purified product is indeed immunoglobulin.

We found a wide range of responses among 4 fish immunised with BSA, with 1 fish showing a minimal response, while the most responsive fish had detectable antibody levels twice that of the second most responsive fish. Previously, Hodgins et al. (1967) and Avtalion et al. (1980) had concluded that BSA was a poor immunogen in rainbow trout and carp. Also, Whittington et al. (1994) found that a similar soluble antigen, ovalbumin, when emulsified with FCA and injected IP into rainbow trout appeared to be an unreliable immunogen. They reported inconsistent antibody responses to ovalbumin, with a longer induction phase compared with the response of fish injected with Vibrio anguillarum.

When sera from both vaccinated groups of barramundi were analysed on the same ELISA, we found that the 3 fish immunised with Cryptocaryon irritans theronts had responses similar to those from the 4 BSAinjected fish, with similar kinetics for the 2 antigens. The responses to both antigens had peaked by $2 \mathrm{wk}$ after the third injections, after which responses from both groups decreased gradually, consistent with the results of Ellis (1989), who noted that the antibody titres in fish, compared to mammals, reach a plateau 20 to $30 \mathrm{~d}$ after antigen stimulation and are maintained for longer peroids. As the $C$. irritans antigen would consist of a mixture of lipids, carbohydrates and proteins in particulate and soluble forms, the amount of any 1 antigen in the mix would be far less than the amount of BSA given to the other group of fish, so it could be argued that the $C$. irritans antigen was the better of the two. Indeed, the BSA may be poorly immunogenic in barramundi, as ovalbumin was found to be in other fish, with the response augmented by an adjuvant effect. Further work is necessary to understand how fish metabolise and respond immunologically to foreign soluble proteins injected with adjuvants in order to establish effective vaccination programs.

The polyclonal anti-barramundi Ig antisera raised in sheep will enable further study of the humoral immune responses in barramundi to Cryptocaryon irritans antigens following successive exposure to the parasites and comparison of responses with those of vaccinated fish. If protection against the parasite can be provided by vaccination, commercial applications developed from this study could prevent debilitating outbreaks of cryptocaryoniasis in aquaculture facilities.

Acknowledgements. The authors thank Peter Burgess for supplying the purified mullet immunoglobulin and Macky Edmundson for performing the N-terminal sequencing. This work was supported in part by a University of Queensland Postgraduate Research Scholarship, and forms part of the doctoral thesis of M.S.B.

\section{LITERATURE CITED}

Andrews C, Exell A, Carrington N (1988) The manual of fish health. Tetra, Morris Plains, NJ

Avtalion RR, Wishkowsky KA, Katz D (1980) Regulatory effect of temperature on specific suppression and enhancement of the humoral immune response in fish. In: Manning MJ (ed) Phylogeny of immunological memory. Elsevier, Amsterdam, p 113-121

Butler JE (1983) Bovine immunoglobulins: an augmented review. Vet Immunol Immunopathol 4:43-152

Clark TG, Dickerson HW, Gratzek JB, Findlay RC (1987) In vitro response of Ichthyophthirius multifiliis to sera from immune channel catfish. J Fish Biol 31:203-208

Colorni A (1987) Biology of Cryptocaryon irritans and strategies for its control. Aquaculture 67:236-237

Diamant A, Issar G, Colorni A, Paperna I (1991) A pathogenic Cryptocaryon-like ciliate from the Mediterranean Sea. Bull Eur Assoc Fish Pathol 11:122-124 
Ellis AE (1989) The immunology of teleosts. In: Roberts RJ (ed) Fish pathology. Bailliere Tindall, London, p 135-152

Estevez J, Leiro J, Santamarina MT, Dominguez J, Ubeira FM (1994) Monoclonal antibodies to turbot (Scophthalmus maximus) immunoglobulins: characterization and applicability in immunoassays. Vet Immunol Immunopathol 41 : $353-366$

Havarstein LS, Aasjord PM, Ness S, Endresen C (1988) Purification and partial characterisation of an IgM-like serum immunoglobulin from atlantic salmon (Salmo salar). Dev Comp Immunol 12:773-785

Hines RS, Spira DT (1974) Ichthophthiriasis in the mirror carp Cyprinus carpio (L.) V. Acquired immunity. J Fish Biol 6 : $373-378$

Hodgins HO, Weiser RS, Ridgeway GJ (1967) The nature of antibodies and the immune response in rainbow trout (Salmo gairdneri). J Immunol 99:534-544

Laemmli UK (1970) Cleavage of structural proteins during the assembly of the head of bacteriophage T4. Nature 227: $680-685$

Leong TS (1992) Diseases of brackishwater and marine fish cultured in some Asian countries. In: Shariff M, Subasinghe RP, Arthur JR (eds) Diseases in asian aquaculture I. Fish health section, Asian Fisheries Society, Manila, p 223-236

Leong TS, Wong SY (1990) Parasites of healthy and diseased juvenile grouper (Epinephelus malabaricus Bloch and Schneider) and seabass (Lates calcarifer Bloch) in floating cages in Penang, Malaysia. Asian Fish Sci 3:319-327

Lobb CJ, Clem LW (1981) Phylogeny of immunoglobulin structure and function-X. Humoral immunoglobulins of the sheepshead, Archosargus probatocephalus. Dev Comp Immunol 5:271-282

Lobb CJ, Clem LW (1983) Distinctive subpopulations of catfish serum antibody and immunoglobulin. Mol Immunol 20:811-818

Lobb CJ, Olson MOJ (1988) Immunoglobulin heavy $\mathrm{H}$ chain isotypes in a teleost fish. J Immunol 141:1236-1245

Lobb CJ, Olson MOJ, Clem LW (1984) Immunoglobulin light chain classes in a teleost fish. J Immunol 132;1917-1923

Markwell MAK, Haas SM, Bieber LL, Tolbert NE (1978) A modification of the Lowry Procedure to simplify protein determination in membrane and lipoprotein samples. Anal Biochem 87:206-210

Editorial responsibility: Wolfgang Körting,

Hannover, Germany
Navarro V, Quesada JA, Abad ME, Taverne N, Rombout JHWM (1993) Immuno(cyto)chemical characterisation of monoclonal antibodies to gilthead seabream (Sparus aurata) immunoglobulin. Fish Shellfish Immunol 3:167-177

Nigrelli RF, Ruggieri GD (1966) Enzootics in the New York Aquarium caused by Cryptocaryon irritans Brown, 1951 (=Ichthyophthirius multifiliis Sikama, 1961), a histophagous ciliate in the skin, eyes and gills of marine fishes. Zoologica 51:97-102

Pilstrom L, Petersson A (1991) Isolation and partial characterization of immunoglobulin from cod (Gadus morhua L.). Dev Comp Immunol 15:143-152

Rasheed VM (1989) Diseases of cultured brown-spotted grouper Epinephelus tauvina and silvery black porgy Acanthopagrus cuvieri in Kuwait. J Aquat Anim Health 1 : 102-107

Sanchez C, Dominguez J (1991) Trout immunoglobulin populations differing in light chains revealed by monoclonal antibodies. Mol Immunol 28:1271-1277

Sanchez C, Dominguez J, Coll J (1989) Immunoglobulin heterogeneity in the rainbow trout, Salmo gairdneri Richardson. J Fish Dis 12:459-465

Seng LT (1987) Recent fish disease problems in South and Southeast Asia and their economic impacts. Fish quarantine and fish diseases in South and Southeast Asia: 1986 update. Repo 1-3|

Sindermann CJ (1990) Principal diseases of marine fish and shellfish, 2nd edn. Academic Press, New York

Warr GW (1982) Behaviour of unreduced polymeric and monomeric immunoglobulins in sodium dodecyl sulphatepolyacrylamide gel electrophoresis. Mol Immunol 19: $75-81$

Whittington RJ (1993) Purification and partial characterisation of serum immunoglobulin of the European perch (Perca fluviatilis L.). Fish Shellfish Immunol 3:331-343

Whittington RJ, Speare R (1996) Sensitive detection of serum antibodies in the cane toad Bufo marinus. Dis Aquat Org 26:59-65

Whittington RJ, Munday BL, Akhlaghi M, Reddacliff GL, Carson $J$ (1994) Humoral and peritoneal cell responses of rainbow trout (Oncorhynchus mykiss) to ovalbumin, Vibrio anguillarum and Freund's complete adjuvant following intraperitoneal and bath immunisation. Fish Shellfish Immunol 4:475-488

Submitted: March 23, 1998; Accepted: September 18, 1998 Proofs received from author(s): March 15, 1999 